\title{
KALANDOZÁS A FÖLDRAJZI NEVEK KÖZÖTT
}

Roving among geographical names

\section{MIKESY GÁBOR}

Lechner Tudásközpont Nonprofit Kft.,

gabor.mikesy@lechnerkozpont.hu

\begin{abstract}
Geographical names provide an inexhaustible source of knowledge about the landscape and the human communities that inhabit it, and as the latter are changing, so do the geographical names, too. This paper does not commit itself to anyone of the many possible approaches, but selects from linguistic (etymological and semantic), historical, cartographic, cultural and administrative topics, with a view to providing contributions to the teaching of geography.
\end{abstract}

Keywords: geographical names, onomastics, linguistic change, name borrowing

Homo nominans (névadó ember; Nicolaisen, W. F. H. 1986) - ezzel a szellemes kifejezéssel lehet a legjobban kifejezni azt, hogy nem léteznek emberi közösségek, nem létezik emberi kultúra anélkül, hogy a körülvevő világ jelentősebb részleteit tulajdonnevekkel ne látná el. Elsősorban az emberi közösség tagjait és a fizikai tér azonosítható részleteit látjuk el nevekkel, de tulajdonnevei vannak, lehetnek csoportoknak, közösségeknek, intézményeknek, állatoknak, a tárgyi világnak, kulturális javaknak stb. A tulajdonnevek olyan hangsorok - akár rendelkeznek közszói jelentéssel, akár nem -, amelyek egyedien azonosítanak egy dolgot, a földrajzi nevek (másképpen helynevek) esetében a fizikai tér részleteit, és ez által lehetővé teszik egy közösség kommunikációját arról a bizonyos dologról. (Könnyen elképzelhető, el is játszható, hogy milyen hosszan és körülményesen, többféle megközelítéssel tudnánk találkozóhelyet egyeztetni a természetben és a településeken, ha nem használnánk helyneveket).

A tulajdonnevek sajátos alakulásmódjuk, változatos jelentésszerkezetük, kulturális beágyazottságuk, esetenként történeti homályba vesző régiségük stb. révén számos információt hordoznak magukban. Ezek tudományos kiaknázásával a névtan, idegen szóval onomasztika foglalkozik, amely tipikusan interdiszciplináris tudományterület. A földrajzi neveket tekintve jórészt a földrajztudomány, a nyelvészet, a történettudomány és a közigazgatás (beleértve több szakterületet a mesterséges névadásoktól a szakági 
nevezéktanokon át a közigazgatási egységekig és a statisztikáig) között helyezkedik el. Egyfelől szüksége van ezekre az ismeretekre az önelvủ névtan műveléséhez, másrészt viszont a névtan hatékony segédtudománya is a felsoroltaknak.

\section{MIK IS AZOK A FÖLDRAJZI NEVEK?}

A földrajzi nevek jelentik a kapcsot a fizikai tér és a rajta élő emberi közösség között, általuk helyezzük el magunkat a Földön, általuk rendezzük és adjuk tovább a térbeli információkat, legyen szó akár egy kis falu közösségéről, akár egy nagy terület komplex leírásáról egy tudományágban vagy egy nemzetközi szervezetben. Helyek és közösségek között szellemi, érzelmi kapcsolat is létrejön, az otthonlét érzése, egyfajta lelki birtoklás élménye: az a hazám, ahol az életteremet meg tudom nevezni. A nevek összekötnek elődeinkkel, akik ránk hagyományozták a neveket. E kötelékek alapján a közösségileg használt nevek jelentős részt képeznek az emberek identitásában, mind helyi és regionális, mind nemzeti szinten. Vannak az írásbeliség kezdetei óta stabilan megmaradt helynevek, és vannak olyanok, amelyek az ásatások rétegeihez hasonlóan követik egymást. A fizikai térnek és a társadalomnak az állandó változása új és újabb névadási-névhasználati motivációt jelent. Egyes megnevezések megmaradnak az egyéni szóhasználat részeként, másokat átvesz a közösség, formájukban véglegesülnek, beépülnek a kultúrába.

Sokféleképpen próbálták meghatározni a földrajzi neveket, ám mindig példák sokaságát találjuk, amelyek valahogy kilógnak a definíciókból. A magyar Földrajzinévbizottság gyakorlatában a következőt veszik alapul: „Földrajzi névnek nevezünk minden olyan nyelvi alakulatot, amelyet a földfelszín természetes (hegy, patak, sziget, sivatag stb.) vagy mesterséges (csatorna, út, dülö, település stb.) részleteinek azonosítására kisebb vagy nagyobb közösségek használnak" (FÁBIÁN P. et al. 1998, p. 15). Gyakorlati szempontú nagyvonalúsággal szemlélve meglehetősen használható meghatározás, ám célszerű kellő rugalmassággal kezelni, ugyanis sem a 'nyelvi alakulat', sem a 'földfelszíni részlet' kifejezéseket nem tudjuk meggyőző kritériumokkal behatárolni, és a közösségi névhasználatot sem lehet számon kérni például a tudományos földrajzi felosztások szakszavain. A 19. századi kataszteri térképeken ilyen körülírásos alakokat is találunk: Major körüli ereklyési járás és putri földek, Alsó kétútközti árkon belül, Három tagosok erdöföldi 1sö, a KSH helységnévtárában a településrészek megnevezései között Bajcsy-Zsilinszky út külterülete, Tanyák (IV. körzet), 060/3 kültelek, a vízügyi nyilvántartásban II/AF-9. árok, Hetesi-patak 2. mellékág stb. Ezeket leginkább valamiféle rendszerkényszer szülte bejegyzésekként értelmezhetünk, amelyek feszegetik a névként való elfogadás határait. A földfelszíni részlet meghatározása is kikezdhetö, hiszen nevet viselhetnek a valóságban elkülöníthetetlen részletek (pl. öblök, melléktengerek), föld alatti (pl. barlangok 
részletei, gázmezők) és megszűnt, elpusztult, de akár kitalált objektumok (pl. a mesebeli Óperenciás-tenger) is. Vajon földrajzi névnek számítanak-e olyan intézmények, nevezetes pontok és helyszínek, amelyek méltán tarthatnak igényt térképeken névvel való feltüntetésre, bár alapvetően nem a földfelszíni részletre való vonatkozásuk adja meg a jelentőségüket (Nemzeti Múzeum, 56-os emlékmü, Gátőrház, Fertő / Neusiedlersee kultúrtáj)? A magyarban szokásos az utóbbiakra a földrajzi megjelölés szakszót használni, külföldi szakirodalmakra ez nem jellemző.

Csak elnagyolt definíciókkal találkozhatunk a nemzetközi irodalomban is. A Névtudományok Nemzetközi Tanácsa (International Council of Onomastic Sciences, ICOS) terminusjegyzékében a helynév (toponima) „egy lakott vagy lakatlan hely tulajdonneve (így egy hegy, víztest, sziget, erdő, város. falu, dülő, legelö, utca, út stb.) neve - pl. Uppsala, Földközi-tenger, Nyugalom tengere (terület a Holdon), Mont Blanc, Szajna, Szardinia, Auckland" (BölCskeI A. et al. 2017, p. 111.). Ugyanitt megjegyzés található arra, hogy a földrajzi név is használható, amennyiben a Földön lévő helyről van szó. Az ENSZ Földrajzinév-szakértői Csoport (UNGEGN) jegyzékében „A Föld egy alakulatára alkalmazott név (tkp. tulajdonnév); a helynév (a topográfiai név vagy toponima) egy sajátos esete" (BöLCSKEI A. et al. 2017, p. 154.).

A nem részletezett meghatározások közvetve utalnak arra, hogy a 'földrajzi név' egy szerteágazó, nyelvektől, kultúráktól, koroktól és esetleg szakmai szokásoktól helyenként erősen függő kategória, így a helynévtudomány (toponomasztika) tárgya teljes terjedelmében meghatározhatatlan. A legfontosabb szempont, hogy azt tekintsük földrajzi névnek, amit az adott közösség földrajzi névnek elfogad (v. ö. HAJDú M. 2003).

A neveket többféleképpen rendszerezhetjük, minden részrendszer eltérő megközelítést igényel. A földrajzi jellegek alapvetően egy természeti (vizek, domborzat, tájak stb.) és egy társadalmi (lakott helyek, közterületek, építmények, közlekedési nevek, és közigazgatási egységek stb.) alapú csoportba illeszthetők. Nem kell és nem is lehet mereven szétválasztani ezeket, hiszen például számos hely vegyes jellegü, vagy egyszerre része több csoportnak, vagy olyan, amely a természetben elkülöníthető ugyan, de a nevét nem ennek alapján, hanem a rajta folyó gazdasági tevékenység alapján kapta. Beszélhetünk továbbá természetes (hosszú idők közösségi használatában formálódott) és mesterséges (hivatalok, testületek, személyek általi) névadásról. Ha a név olyan jelentésbeli mozzanatot tartalmaz, amelynek látható, tudható kapcsolata van a névvel jelölt tereptárgyhoz, akkor motivált nevekről beszélhetünk, ellenkező esetben motiválatlanokról. Szokásban van megkülönböztetni makro- és mikrotoponimákat egyrészt aszerint, hogy milyen méretü, és hogy milyen széles körben ismert az a bizonyos részlet, így például a Duna, a Kékes, a tájak, a helységek stb. az első, míg az utcák, a domboldalak, ültetvények, általában egy településen belüli, csak a helyiek által ismert nevek az utóbbi 
kategóriába tartoznak. Természetesen az utóbbi kategóriákban sincs mód merev szétválasztásra. A megfelelő kategorizálás - hozzátéve még a nyelvtani szerkezet szerinti osztályozást is - különösen a helyesírásban kap jelentőséget.

Nagy különbségek vannak abban, mit neveznek el és mit nem. Van, ahol csak a hegyek kapnak nevet, a köztük levő völgyek nem, és van olyan is, ahol csak a völgyek. Van, ahol a kiterjedt dülőknek van nevük, és van, ahol csak a dülöutaknak van nevük, a köztük levő területeknek nincs. Bizonyos munkákban a földrajzi neveknek hézagmentesen le kell fedniük a területet (ilyenek például a tájkataszterek, a régebbi kataszteri térképek), így ezekben a névanyag a lehatárolt egységekhez idomul (esetenként szemben a hagyományos helyi névhasználattal), máshol az a természetes, hogy a legjellemzőbb pontoknak, vonalas tereptárgyaknak és foltoknak van nevük, és ezek között nincsenek éles elválasztó vonalak. Minden közösségben sajátos névrendszer alakul ki.

\section{NYELVI MEGKÖZELÍTÉSEK}

A földrajzi neveket általában eleve a főnevek közé sorolják be, bár bonyolult szerkezetűek is adódnak köztük. Így tartozhatnak ide az önálló szavakon (Balaton, Mecsek, Major, Ázsia) kívül szószerkezetek (Zempléni-hegység, Boldogasszony magasa, Bakonyérre dülö, Afrikai-árokrendszer), többes számú (Kárpátok, Fülöp-szigetek, Kertek), ragos (Mocsolyáknál, Tereskei határnál) és névutós (Hársas mögött, Rakacai út alatt, Érfeletti) alakok, sőt mondatértékủ egységekből formálódott névalakok (Bárnevolna, Nekaszáld). Helynevek között találunk betü- és mozaikszavakból keletkezetteket (Benelux, OFBföldek), számozottakat (XII. kerület, III/4. csatorna). Átmenetet képeznek az esetenként tulajdonnévi szerepkörben álló földrajzi köznevek (Hegy, Szölö, Delelő, Major). Feszegetik a határokat, de kétségkívül élő beszédből, jó közléssel származnak a következő „földrajzi nevek" is: Széles-földek Szölö alatt, Széles-földek a híd felé. Igazán alaki (morfológiai) vagy szófaji kritériumai nincsenek annak, mit tekinthetünk földrajzi névnek. Mégis mint minden kultúrában - kialakul a helynevek hozzávetőleges rendszere, azok a tipikus, leggyakrabban előforduló szerkesztési módok és lexikai csoportok, amelyeket névszerünek tartanak, és mintaként szolgálnak újabb nevek alkotásakor. A magyarban az utóbbi időben például annyira a két tagból, egy megkülönböztető részből és egy földrajzi jellegre utaló köznévi részből álló nevek a leggyakoribbak (Gombás-patak, Tüskés-dülö, Fehér-tó, János-hegy Váli-völgy stb.), hogy az adatközlők gyakran önkéntelenül is megtoldják használt helyneveiket egy földrajzi köznévvel.

A földrajzi nevek fejlődésének megértéséhez röviden kitérést kell tenni a nevek jelentéstanához (J. Soltész K. 1979, HajDú M. 2003). Általános vélemény szerint mivel a név legfontosabb funkciója az egyedi azonosítás, a név jelentésének fókuszában maga a jelölt 
dolog áll (ezt szokták denotatív jelentésnek hívni). Minden más jelentéstartalom (ezt szokták konnotatív jelentésnek nevezni) csak kiegészíti a fö funkciót, így a vélt vagy valós közszói jelentések is. Együtt jelentésszerkezetröl beszélhetünk. Ebbe beleérthetjük a leíró tartalmakat (a Bükk névben utalás van a jellemző fafajtára, a Görbe-érben egy kis vízfolyás alakjára, a Feneketlen-tóban a vízmélységre stb.) és az asszociatív értékét (a Hadi-földek háborús képeket idéznek fel, a Csengőd kellemes, a Dögös kellemetlen hatást kelt, az Ardics, Vinyicska, Sucvold, Tödl nevek hallatán a magyartól különböző etnikai közösség képe merül fel). Valamennyi földrajzi név valamely nyelvben közszói jelentéssel bíró elemekböl épült fel, viszont a tulajdonnévvé válás folyamatában a jelentésszerkezet egyetlen funkciója válik hangsúlyossá: hogy a név hozzátapadjon egy bizonyos földfelszíni részlethez. A közszói jelentés innentől kezdve el is tűnhet, át is alakulhat, teljesen ki is cserélődhet. Félreértést okozhat, ha valaki a jelenlegi közszói jelentések alapján viszonyulna a Sima, Tejfalusziget, Apácaszakállas, Pogányszentpéter stb. nevekhez (hiszen Sima falu, amelynek neve a Simon személynév alakváltozatából ered, éppenséggel hegyes vidéken van, Szent Péter nem volt pogány stb.), vagy domborzati és víznévként azonosítaná a Köszárhegy, Kozmadombja, Sárospatak, Fehértó, Máramarossziget féléket. A viszonylagos alaki állandóság fontosabb tulajdonsága a neveknek, mint a járulékos (konnotatív) jelentéstartalmak őrzése, így a nevek más és más utakat járnak be, mintha lenne közszói jelentésük. Éppen ez a tulajdonságuk teszi lehetővé egyrészt azt, hogy a nevekben régi idők kövületei (régi nyelvi, kulturális, etnikai közösségek emlékei) megmaradhassanak, másrészt hogy szinte akadály nélkül vándoroljanak egyik nyelvből a másikba. Ennek jószerivel egyetlen korlátja az, hogy az átvevő nyelv milyen hangalakokat tud magába fogadni, pl. több szláv nyelvben Seleuš lett a magyar Szőlősökből, a románban az -oara végződés a magyar vár szóból: Segesvár > Sighişoara, Hunyadvár (ma Vajdahunyad) $>$ Hunedoara stb.

Az etimológia tudománya az, amely arra törekszik, hogy a szavak eredetét felfejtse, s mint ilyen, a közszói jelentéssel csak részint bíró földrajzi nevek világában különös jelentőséggel bír. Müvelésében a legfontosabb szempontok, hogy egyrészt a lehető legrégebbi írásbeli források jelentsék a kiinduló pontot, másrészt fel legyenek tárva a név környékének beszélt nyelvei, valamint a nyelvek változásának irányai és a nyelvek közti kölcsönzés szabályszerűségei. A Zala megyei Misefa ugyan látszólag a mise és a fa közszavak összetétele, de ha az első elöfordulást (1352: Myxefolua) nézzük, máris látjuk, hogy egy 'Mikse személy által birtokolt falu' jelentés van a névben (KIss L. 1988). A -falva utótag $-f a$ alakúra egyszerüsödése a nyugat-dunántúli régióban az egész helynévrendszert érintette, így a -fa végü helynevekben minden esetben a „valakinek a falva” szerkezetet kell keresnünk: Farkasfa, Kálócfa, (Lendva)jakabfa, Orbányosfa, Pósfa stb. (KÁzmÉr M. 1970). Fény, Mezőfény, Jászfényszaru településnevekben ma a világosság 
jelentésű fény szót sejthetjük, a régi adatok viszont rávilágítanak, hogy nem ezt, hanem a föveny szó korai alakváltozatát kell keresnünk benne. A régiségből bőven adatolható a - gy helynévképző, ennek ismeretében máris világossá válik a Somogy, Kórógy, Egregy féle nevek eredete, hasonlóképpen a meder jelentésü ágy szavunk ismeretében az Almágy, Hárságy, Szilágy féléké (BÉNYei Á. 2012). Nagykikinda nevében a második elem megegyezik a szerb változattal, és a magyarban csak a Bánság újranépesítésekor honosodott meg. Amennyiben a török előtti forrásokat is megnézzük, kiderül, hogy a szerb név viszont a magyar kökény szó származékára, egy nagy valószínűséggel Kökénd hangzású névre megy vissza (hasonlóképpen magyar előzménye van a régióban Apatin, Temerin és sok más visszakölcsönzött névnek). Számos helynevünk úgy alakult, hogy egy -k végü alapszóhoz a -csa/-cse helynévképző társult, majd a két egymás mellé került mássalhangzó helyet cserélve illeszkedett a nyelvi rendszerbe: a Kék személynévből képzett Kékcse név Kécske alakú lett; a bükk, ill. a derék közszót találhatjuk eredendően a hasonlóképpen változott Bicske és Derecske nevekben (Kiss L. 1999).

A közszói jelentések elhomályosulása vagy eltünése okozhatja az idők során, hogy más jelentések is - sokszor népetimológiásak, azaz hangalaki hasonlóságon alapuló szóértelmesítések - tapadhatnak a nevekhez: az erdélyi Alparét és Borberek az eredeti német Albrecht és Burgberg nevek „értelmes” magyar változatai, a káliz népnév Káloz alakban fejlődött falunévvé, ebből lett (Buda)kalász; a baranyai Lánycsók az előző századfordulóig még Lancsuk volt. A zalai Kozmadombja templomát a párban tisztelt két szent, Szent Kozma és Szent Domján tiszteletére szentelték, az eredeti falunév róluk Kozmadomján lett, amiböl elöször a szóvégi - $n$ kopott le, mert helyhatározói ragnak érezték, utána $a-b$ betoldásával ez birtokos szerkezetté alakult. A szó elejéröl az $a$ hang (mert névelőnek érthették) és az $i$ viszonylag gyakran lekopott: Aborgátából Borgáta, Amadéfalvából Madéfalva lett (KIss L. 1988), ill. a Zsáka és Zsákod falvaink sem a zsák közszóról, hanem az Izsó és Izsák személynevekből kapták nevüket (KÁLMÁN B. 1973).

A magyar nyelvnek a Kárpát-medencei megtelepedést követő első századokban azaz a helynevek korai rétegeinek kialakulása idején - olyan markáns tulajdonságai voltak, amelyek manapság nem, vagy csak lényegesen gyengébb formában jelentkeznek. Néhány példa ezek közül:

- nem türtük a mássalhangzók torlódását szó elején (a főember jelentésủ szláv knež(a) szóból egy-egy bontóhang beillesztésével keletkeztek a Kanizsa, Kenese és Kinizs neveink, a nyírfás jelentésű breznicából a Berzence, a sós jelentésü slanacból a Szalánc, a Granból Garam stb.);

- törekedtünk a magánhangzó-harmóniára, azaz arra, hogy egy szóban csak magas (azaz e, é, i, í, ö, ö, ü és ü), vagy csak mély (a, á, o, ó, u és ú) magánhangzók legyenek, pl. Milvány > Molvány, Toplica > (Csík)taploca, Žil(i)na > Zsolna; 
- tendencia volt arra, hogy a szavak közepén ne legyen két nyílt (azaz egy mássalhangzóból és egy magánhangzóból álló) szótag: Besenyő > Besnyő, Péter $\sim$ Petur $+-i$ képző > Petri, Német + -i > Nemti, Rákos + -i > Ráksi stb.;

- az egész magánhangzórendszer elmozdult a lejjebb képzett hangok felé, így alakult a szláv Bisztricából Beszterce, a korábbi Potvorcból Patvarc, a Mogyoródnak van (Balaton)magyaród változata stb.

A fenti törvényszerüségek eredőjeként könnyen magyarázható például, hogy a szláv Krupinából és a magyarba a latinból érkezett Priamus személynévből hogyan fejlődött a magyar Korpona, ill. Perjámos forma, továbbá a névalakulások jelzik, hogy azok csakis magyar nyelvi környezetben mehettek végbe.

A szabályszerüségek többféle alakot is eredményezhettek. Két folyónevünkben hasonlóképpen maradt meg a középkori hev 'meleg' és a jó 'folyó' szó kövülete, vannak is Hewyo, Hevio írott adatok. Miután elhomályosult a szóösszetétel tagjainak közszói jelentése, egyszerű szóvá alakult, de úgy nem felelhetett meg a magánhangzó-harmónia igényének, és az egyik helyen magas hangrendűvé (Hejő), a másik helyen méllyé változott (Hájó).

Támpontokat adhatnak a földrajztudomány számára azoknak a szavaknak az értelmezései, amelyek a köznyelvből kivesztek, ám a nevekben megmaradtak. A mál(y), mány, már stb. alakváltozatokban, helynevek százaiban földrajzi köznévi utótagként élő szó jelentése déli, azaz meleg domboldal volt: Farkasmály (Gyöngyös), Bükk-mál (Magyarhertelend), Verö-máj (Abaújkér), Meleg-mányi-völgy (Pécs), és ugyanez van a Mány, Mályi, Kemesmál falunevekben is. A pilis és a szár kopasz, növényzettel ritkán borított helyeket (föleg dombokat, hegyeket) jelölt: Csák-pilis (Felsőtárkány), Pilis-tető (Pétervására), Piliske (Tardona), Szár-hegy (Bózsva, Mád, Sárazsadány), Szár-völgy (Cserépfalu), Szár-kő (Fony). A szád 'völgynyílás' szó van a Szádelő, Szádvár, Bikszád nevekben. A szent jelentésü egy szóval alakult ki a Sopron megyei Hegykő neve (a szókezdő $h$ utólagos népetimológiás betoldás), amit igazol az is, hogy a név német változata Heiligenstein, azaz 'szent kö', ami nyilván akkor alakult ki, amikor még élő volt a név magyar jelentése.

\section{TÖRTÉNELEM A FÖLDRAJZI NEVEKBEN}

Az etimológia átvezet a földrajzi neveknek a történettudomány terén való hasznosításához. Azt már láttuk, hogy a nevek eredeti alakjai, továbbá annak a folyamatnak a leírása, hogy mely nyelvből és hogyan alakultak a nevek, etnikumoknak az adott helyen való jelenlétére engednek következtetni. Csakhogy óvatosan kell ezzel is bánni. Az etimológia csak a szavakra vonatkozik, márpedig a névadásban társadalmi szokások 
rendszere sejlik fel koronként. A korai magyar településnevekben a legerőteljesebb csoportot azok a nevek képezik, amelyek személynevekből alakultak bármiféle nyelvtani képzési mozzanat nélkül. A legismertebb példák a fejedelmekről és más, honfoglalás utáni előkelőségekről elnevezett települések: Fajsz, Solt, Taksony, Tass, Szabolcs, Csanád stb. A puszta személynevekből származó helynevek rendszerét szokás nomád névadásnak is nevezni, ugyanis a párhuzamai csak a keletebbi, nomád múltra visszatekintő népeknél lelhetők fel. Így tehát a szláv, pl. Bogyoszló, (Hajdú)szoboszló, Vajszló, Bodmér, Zsadány, vagy a germán, pl. Arnót, Balf, Hont, Lipárt eredetű személynevekből alakult településnevek esetében is tudnivaló, hogy azok magyar névadás eredményei, függetlenül a névben megörökített személy etnikumától, mert a szláv és germán népeknél nincs meg a puszta személynevekből való névadás. Magyar sajátosság, így etnikumjelölő értéke van a heti vásárok napjából képzés nélkül alakult helynevek típusának is: (Csík) szereda, (Tardos)kedd, (Mura)szombat, (Csallóköz)csütörtök stb.

A törzsek, nemzetségek, etnikumok nevéből ugyancsak mindenféle képzés nélkül keletkeztek helységnevek a legkorábbi időkben, megmutatván a honfoglalásban részt vett, vagy nem sokkal később csatlakozó keleti etnikumok nevét. A besenyők nyomai szerte-széjjel megtalálhatók a dél-somogyi Rinyabesenyőtől a háromszéki Sepsibesenyőig. Az iráni eredetű mohamedán kálizok emlékét Káloz, Kálozd és (Buda) kalász nevének eredeti alakja őrzi. A kazár vagy kozár népnevet találjuk pl. a Salgótarján melletti Kazárban, a baranyai Kozármislenyben és még tucatnyi helyen. Széles körü egyetértés van abban is, hogy a Berény, Bercel, Böszörmény, Ladány, Oszlár, Örs, Tomaj, Varsány féle helynevek valamely keleti nép egy-egy törzsének, nemzetségének emlékét őrzi, pl. a bercelek a volgai bolgár államból szakadhattak ki. Itt talált népekre és a korai kapcsolatokra utalnak a horvát (Disznóshorvát), a lengyel (Nagylengyel), a morva jelentésü maróc, marót (Hegyhátmaróc, Pilismarót), a bolgár jelentésủ nándor (Magyarnándor), a német (Felnémet), a vallon jelentésü olasz (Nagyolasz), a későbbi szlavónokra és szlovénekre használt tót (Husztót) stb. népnevekkel alkotott településnevek hosszú sora (Kiss L. 1999).

A törzsi helynevek kiválóan mutatják, hogy honfoglaláskor a medence középső részeit szállták meg eleink, körben széles gyepüt hagytak más országok felé. A több száz törzsi helynév túlnyomó többsége a Dunántúlra (Megyer, Gyulakeszi, Hajmáskér, Felsőnyék), az Alföldre (Bélmegyer, Köröskisjenő, Tiszakürt), a Kisalföldre (Csallóközkürt, Garamkeszi, Nagymegyer) és az Ipoly medencéjére (Balassagyarmat, Ipolynyék, Salgótarján) esik, míg a Fertőtől nyugatra, a Nyitra-Kassa vonaltól északra, illetve Erdélyben (Szamosjenő) csak elvétve találunk ilyeneket (Kiss L. 1999). Erdély, Szlavónia, valamint az északi és nyugati gyepü megszállása azokra az időkre esik, amikor a törzsnevek visszaszorultak a helynévadásban. Ellenben a talmács, tolmács szóval alkotott helynevek éppen 
a megszállt területek külső szélein, stratégiai védelmi pontok közelében helyezkednek el. Nagytalmács a Déli-Kárpátok elöterében, az Olt áttörésénél fekszik, Garamtolmács a Garam völgyének kapujában a Selmeci-hegység és a Madaras felé, Kistolmács a nyugati gyepű szélén a Mura völgyében. Magyarázata, hogy a talmácsok (vagy tolmácsok) a besenyők egyik törzsét alkották, akik kiszakadván népük kötelékéből a magyar fejedelmek szolgálatába álltak, és a gyepü védelmét látták el.

A 12. század elejétől mintha elvágták volna ezt a képzés nélküli névtípust, és elkezdődött az -i képzős nevek térhódítása. Az (Eger)csehi, (Sümeg)csehi, (Bán)horváti, (Erdő) horváti, (Tolna)némedi, Nemti, (Bodrog)olaszi, (Szepes)olaszi, (Kis)oroszi, (Gyöngyös) oroszi, (Káptalan)tóti, (Lengyel)tóti településnevek ugyancsak erős korszakjelző értékkel bírnak: csak az Árpád-kor derekára jellemzők. A még később kialakuló etnikai kapcsolatok helynévi vonatkozású emlékei jobbára a megkülönböztető előtagokban jelennek meg, pl. Oláhlápos, Rácalmás, Szerbszentmárton (RÁcz A. 2016).

A földrajzi nevek számos adalékot szolgáltatnak egy vidék etnikai jellegének megállapításához, megváltozásának vizsgálatához, népmozgások nyomon követéséhez. A Nyitra megyei Galgóc városa a nevét bizonyosan a 'galagonyás' jelentésü, kb. glogovec alakú szláv szóból vette (ez utóbbinak mint helynévnek viszont nincs nyoma írott forrásokban). 1113-ban a zobori apátság egyik oklevelében fordul elő először, méghozzá a teljesen magyaros Golguz alakban: a szókezdő mássalhangzó-torlódás feloldása megtörtént, a második nyílt szótag magánhangzója kiesett, az -ovec végződés szabályszerüen -óc-ra egyszerűsödött. (Egyébként a város területén találták a régészek az első honfoglalás kori tarsolylemezt is.) A város lakosságában oly mértékben növekedett meg a német etnikum, hogy az általuk használt Freystadtl név adta a mintát a harmadik hullámban érkező szlovák betelepülőknek, így lett hagyományosan Frajstak a városka neve a szlovákban. A 19. századra a szlovákok kerültek túlsúlyra, majd a Trianon után felálló csehszlovák állam a helynevek szlovákosításának első hullámában a tudományosan kikövetkeztetett Hlohovec nevet állapította meg (a szlovákban a korai $g$ hang $h$-vá alakult), éppen úgy, mintha a szláv helynév a magyar államalakítás előtti időktől töretlenül fejlődött volna.

A 16. század derekán az ország legnyugatibb, ma nagyobb részt az ausztriai Burgenland területére eső szélére mintegy százezer főnyi horvát telepes érkezett (20. századi kifejezéssel a gradistyei horvátok). Korábban e német-magyar vegyes lakosságú vidéken kialakult mind a német, mind a magyar településnevek rendszere, a bevándorló horvátok már létező falvakba telepedtek, melyeknek a nevét nyelvileg adaptálták, s így az ő átvételeik kiválóan mutatják a korabeli nyelvi és etnikai viszonyokat. A magyarból vették át például a Sabara (<Szabar) nevet, és nem a német Zuberbachot, hasonlóképpen Filežt (< Füles) és Keteljt (< Kethely) használnak Nikitschcsel és Neumarkttal szemben. 
Ellenben pl. Monyorókerék és Lövő esetében a német alakok bizonyultak meghatározónak: Eberava $<$ Eberau, Šice $<$ Schützen.

Tanulságos a délvidéki magyar helységnevek sorsa a török hódoltság alatt és után. Igen hosszú sora lenne az örökre eltűnt település- és egyéb helyneveknek, ilyenek pl. Bács megyéből Gazdagandrásfölde, Kereszténytelke, Pelefalva, Savar (GYörffy Gy. 1963). A törökök elől menekülő magyarok helyére délröl ugyancsak a törökök által elűzött szláv csoportok érkeztek. A magyarság huzamos együttélését mutatja az átadott helynevek hosszú sora: Bánmonostora > Banoštor, Erdőd > Erdut, Erdővég > Erdevik, Nagyolasz > Mandjelos, Szilszeg > Susek, Tard > Tordince, Újlak > Ilok stb. (KIss L. 1999). A törökök kiűzése után, a 18. században szervezetten újranépesített vidék egyik vezető etnikuma a magyar lett, ezt az időt viszont már nem érte meg a helyi magyarság. Az ekkor kialakuló új magyar névhasználat a megszakadt folyamatosság következtében a délszláv formákra épült, számos helységnevet módosult alakban kölcsönöztünk vissza, így például a török előtti Apáti és Temeri egy tipikus délszláv végződést kapott, majd így, Apatin és Temerin alakban lettek újra a magyar névállomány részei. Hasonló történet igen sok van a már említett Kikindán kívül is: Nyék > Nyikinci > Nyékinca, Pancsal > Pancsevo > Pancsova stb. Számos esetben a hivatalos névmegállapítások idején (az elöző századforduló környékén) még magyarabbá akarták tenni a neveket, viszont az eredeti névadási motivációt jócskán eltéveszthették. Példaként álljon itt az eredetileg Feketeegyház nevet viselö falu esete! Ez a szerb nyelvben a török időkben Feketicsre módosult, és hosszan ezt a nevet használta a visszatelepülö magyarság is. 1894-ben hatósági úton a helyhez semmilyen formában nem kötődő Feketehegy alakot állapították meg, majd a törzskönyvezés után nyerte el az egybeírt Bácsfeketehegy alakot. Hasonló utat járt be Bükedegyház > Bikity > Bácsbokod, Szegegyház > Szikics > Szeghegy, Csontafejér > Csontavir > Csantavér stb. Az Eszékhez közeli, a török előtti forrásokban Hagymás néven szereplö (de vélhetően hajmásnak ejtett) település neve a horvátban Aljmaš alakot vett fel, ebből Almásként került vissza a magyarba, majd Apfeldorfként a németbe.

A nevek költözése, újabb helyeken való felbukkanása utalhat valóságos népmozgásra, mutathat tájakat átívelő birtoklást és szimbolikus kapcsolatot is. Az abaúji Szepsi (ma Moldava nad Bodvou) város neve onnan ered, hogy a tatárjáráskor elpusztult vidéken a Szepességből érkező telepesek alapították a várost: Szepes + -i > Szepesi > Szepsi. Ráckeve az Árpád-kori Ábrahámtelke helyén áll; a török elől rácok menekültek az al-dunai Keveváráról (az egykori Keve vármegye székhelyéről) a Csepel-szigetre, akik hozták magukkal korábbi lakóhelyük nevét, ami utólag a rác előtaggal is kiegészült. A székelyeket a 12. század derekán II. Géza telepítette a mai Székelyföldre, párhuzamosan a helyükre érkező, utólag szászként emlegetett németek betelepítésével. Egyes székely székek még a régi, Erdély közepi lakóhelyükön szilárdultak meg, pl. Kézden, Orbón, Sebesen, és ezt a 
nevet vitték az új lakóhelyükre is, és ezek felhasználásával képződtek itt a településnevek is: Kézdiszéken Kézdivásárhely, Kézdimartonfalva; Orbaiszéken Orbaitelek; Sepsiszéken Sepsiszentgyörgy, Sepsibodok stb. helynevek jöttek létre (a Sepsi név egyébként a Sebesből ered: Sebes $+-i>$ Sebesi $>$ Sebsi $>$ Sepsi). Az anyatelepüléseket ma Szászkézd, Szászorbó, Szászsebes néven ismerjük. Szeremle szerémségi telepesektől kapta a nevét, Szelezsény pedig sziléziaiaktól. A Balaton-felvidéki Óbudavár (a középkorban csak Budavár) falu a birtokosáról kapta a nevét, ez ugyanis a budai-óbudai káptalan volt.

A mikrotoponimákban ugyancsak megmutatkozik a történelem. Számos elpusztult falu emléke megmaradt a dülőnevekben, így például a Baranya megyei Hídága és Koppány falvak neve Kékesd és Harkány, a borsodi Jétyö, Szinye és Vajla falvak neve Bánfalva, Alsózsolca és Harsány egy-egy dűlőjének nevében (GYöRfFY Gy. 1963). A közelebbi múlt történelmi változásai is inkább a mikrotoponimák világában hagytak nyomot. A 20. század folyamán Magyarországon három nagyobb földosztási és két nagyüzemszervezési hullám söpört végig. Az utóbbinak a névadásra való hatására jó példa a téeszek nevéből alakult major- és földterületnevek: Dózsa-kert, Kossuth-föld, Rákóczi-dülö, Táncsicstanya stb. A földosztások közül különösen az 1920. évi, Nagyatádi Szabó István nevéhez köthetö hagyott erős nyomot a névanyagban. Törvény szabályozta a földhöz jutás jogalapját. Ahol a hadirokkantaknak osztottak ki egy darab földet, ott lettek a Rokkant-földek (pl. Bölcske, Csempeszkopács, Szőlőskislak) és a legnagyobb vérveszteséggel járó csatára emlékeztető Doberdók (Farkasfa, Ják, Torony). Hadiárvaság és hadiözvegység jogcímén keletkeztek értelemszerűen az Árvák (Nagylózs), Árva-földek (Füzesabony, Erzsébet), Árva-dülő (Poroszló, Mesztegnyö) és a Hadiözvegyeké (Vécs). Ahol viszont a 3 hadi jogcím mindegyikén osztottak, ott lettek a Hadi-földek (Katymár, Felsőszentiván, Csörötnek, Rönök, Kalaznó, Kisdorog, Murga), Hadi-dülők (Felsőnána). Mezőgazdasági munkásoknak, avagy közkeletüen (agrár)proletároknak is osztottak földet, így a Proletár (nyelvjárási Poletár) féle nevek az előbbiekhez hasonlóan az 1920 utáni földjuttatás jogcímére utalnak, nem másra, és semmi közük nincs a kommunista korszakokhoz, proletárdiktatúrához. Sok száz ilyen nevünk van. Ugyancsak százas nagyságrendben lett névrendszerünk része a Vitéztelek, ugyanannak a törvénynek az első világháborús helytállást jutalmazó helyei okán. Az utolsó névtípus ebben a csoportban magának a törvény szerzőjének állít emléket: Nagyatádi-föld, -tag, -telek, -osztás van számos helyen az országban (Mıкesy G. 2008).

\section{NYELVI ÉS IDEOLÓGIAI ALAPÚ BEAVATKOZÁSOK A NÉVANYAGBA}

A földrajzi nevek jelentésszerkezetében az azonosításon túli, járulékos tartalmak sorában kiemelkedő hely illeti meg a név nyelvét, ezzel párhuzamosan az eredeti névadás viszonyainak felidézését. Ez a szimbolikus kapocs az, amely a társadalmi-történelmi 
változások sodrában ütközőponttá teheti a helyneveket, különösképpen többnemzetiségü vidékeken, de arrogáns ideológiák egy nyelven belül is befolyásolhatják a névhasználatot. A fizikai térért való versengés során a nevekben nemcsak a táj kulturális megragadásának, hanem az elragadásának, a közös múlt kisajátításának eszközét is látni lehet: „Cuius regio, eius nomen?” [Akié a hatalom, azé a név?] - tette fel a kérdést a neves névkutató, etimológus Kiss Lajos (1992). A mi közép-európai térségünk meglehetősen terhelt ebből a szempontból. A földrajzi nevek egy részére (föképp a helységekre és a közterületekre) vonatkozóan az állami adminisztrációknak közvetlen hatása volt, de a térképezéssel foglalkozó intézmények állami felügyelete révén a többi névtípuson is érezhető az elvárásoknak való megfelelés, a mesterséges névadás lehetőségeit használva.

Nyelv- és névhasználatra vonatkozóan igen sok ideológiai árnyalatot lehet elkülöníteni (LANSTYÁk I. 2017), ezek a 20. század elejétől különös erővel hatottak főleg a hivatalos és a térképi névhasználatra. Talán ezek közül az alábbiak a legfontosabbak.

- Az államnyelvi elv (nyelvi etatizmus): az állam és a nemzeti nyelv közötti rendkívül szoros kapcsolatot tételező meggyőződés, amely többek között abban a gondolatban nyilvánul meg, hogy az államhatárok egybeesnek az etnikai és nyelvi határokkal, vagy legalábbis az volna a jó, ha egybeesnének. Ebben a felfogásban a kisebbségi nyelvek jelenléte egy-egy országban zavaró tényező, melyet legjobb lenne nyelvviszszaszorító politikával kiküszöbölni.

- A nyelvi többség elve (nyelvi majoritizmus): az a meggyőződés, hogy egy-egy politikai egységen (országon, esetleg tartományon vagy másképpen kijelölt közigazgatási területen) belül a nyelvi többséget többletjogok illetik meg, vagy a másik oldalról nézve: természetes, hogy a nyelvi kisebbségek nem rendelkeznek ugyanannyi nyelvi joggal, mint a nyelvi többség.

- A nyelvi hazafiasság elve (nyelvi patriotizmus): az a meggyőződés, hogy a nyelvhasználat önmagában is, a közlés tartalmától függetlenül, pusztán a szóválasztás folytán lehet hazafias vagy akár hazafiatlan tett, sőt használhat vagy árthat a nemzetnek, azaz vannak nyelvi formák, melyek használata hazafiasságnak, más formák használata pedig hazafiatlanságnak minősíthető, sőt bizonyos formák használata összhangban van a nemzet érdekeivel, más formák használata sérti a nemzet érdekeit, árthat a nemzetnek.

- Kifejezetten földrajzi nevekre vonatkozik az államnyelvi névhasználat elve (nyelvi onoetatizmus): a helynevek vonatkozásában az a meggyőződés, hogy a településneveknek, tájneveknek, közigazgatási neveknek, sőt a különféle földrajzi objektumok neveinek nyelvi formája összhangban kell(ene) legyen az államszervező etnikum nyelvével. Ha nincs meg ez az összhang, az állami hatóságok jogosultak helyneveket akár az adott településen, ill. régióban élők beleegyezése nélkül is megváltoztatni. 
Nézzünk körül először a saját házunk táján! A magyar állam a 20. század első évtizedében több ezer német, román, szlovák, szerb eredetű, de a magyar közigazgatásban régóta használt, bevett helységnevet magyarosított meg az eredetileg egyébként csak közigazgatási egységesítésre szolgáló folyamat (a törzskönyvezés) keretében. Magyar(os) nevek jöttek létre fordítással, pl. Vodnik > Vizes, Vracsevgáj > Varázsliget, Valealunga > (Béga)hosszúpatak, Vránje > Varjad, magyaros hangzásúvá alakítással: Grid > Göröd, Szmolnik > Szomolnok, Vrászló > Varászló, vagy teljesen új, de magyar nevek adásával, pl. Budiszava > Tiszakálmánfalva, Karavukova > Bácsordas, Ochtina > Martonháza, Szkerisóra > Aranyosfó, Vorocsó > Kapuszög (Mező A. 1982, 1999).

A kataszteri térképezés egyik fontos alapegységét jelentő dűlők nevére vonatkozóan 1904-ben központi földmérési utasítás szabta meg, hogy ha az állam nyelvére lehet fordítani, akkor fordítsák le. Az addig nemzetiségi nyelvi tekintetben jószerivel toleráns térképi névhasználatban megjelentek a helyben ismeretlen, sok esetben téves fordítások: Stockweingärten > Botos, Hochgipfel > Csucsos (Keszőhidegkút, Tolna m.), Kodhraszta $>$ A tölgynél, Meszárszkiput > Mészáros út (Kökény, Baranya m.) stb. (Mıkesy G. 2019).

Hasonló folyamatok zajlottak a topográfiai térképek körében is. A Monarchia idejének katonai felmérésein az az elv látszik érvényesülni, hogy földrajzi nevek nyelve ugyanúgy hozzátartozik az ábrázolt területek jellemzőihez, mint például a domborzat, így törekedtek valamennyi tulajdonnévnek felfogott nyelvi elemet az adott hely lakosságának domináns nyelvén feltüntetni. Az önállósult magyar katonai térképészet (1919től) névírási gyakorlatában egyre fokozódó mértékben magyarosították a névanyagot valamennyi térképtípuson (a turista- és más polgári célú térképeken is), figyelmen kívül hagyva a kisebbségi viszonyokat, majd a bécsi döntések után visszacsatolt területeken is kizárólagossá lettek a magyar elnevezések. A névanyag magyarosításának három alapvető módszere volt:

- az idegen nyelvü neveket egyszerüen elhagyták;

- alaki hasonlóság vagy jelentésbeli egyezőség alapján állapítottak meg magyar neveket;

- mindenféle előzmény nélküli (kitalált) magyar nevekkel láttak el teljes szelvényeket.

Az ÁTI (a honvédelmi kötelékben működő, de hivatalosan a pénzügyminisztériumhoz tartozó Magyar Királyi Állami Térképészeti Intézet) turistatérképeinek magyarosított helynevei köszönnek vissza mai térképeinkről is. A példák a Pilis turistatérképéről vannak: Herrentisch > Urak asztala, Kapuzinerhaufen > Barát-halom, Predigerstuhl > Prédikálószék, ill. Hrabina > Gyertyános, Messelia > Mesélö-hegy, Slanicka > Sós-hegy stb.

Az 1941-1944 között készült teljes 1:50 000 méretarányú katonai térképsorozaton a dél-bácskai térségben, például Palánka és Dunagálos között valamennyi délszláv és német név lekerült a térképről. Ezek egy kis részét lefordították: Ziegelofen > Téglavető 
földek, Gläserner Berg > Üveges hegy (Dunagálos), Saliter Äcker > Salétromos szántók, Jabukovac > Almás (Palánka), a terület legnagyobb részére viszont az adott helyen teljességgel előzmény nélküli, ám a magyar politikai és kultúrközösséghez tartozást erősítő, a megemlékező névadás kategóriájába sorolható helyneveket írtak: Horthy Miklós-dülö, Mátyás király-dülö, Szent Erzsébet-dülő, Szent István-dülö, Széchenyi István-dülö. A Keleti-Kárpátokban a front közeledtével gyorsított ütemben végeztek terepi felmérést, a névanyag teljes egészében a budapesti székhelyen készült a ruszin és román nevek hangalakjának vagy közszói jelentésének felhasználásával (a példák a Máramarostól keletre elterülő vidékröl származnak): D. Corbului > Hollóhegy, Picniata > Pincés t., Pliski $>$ Piliske, Ladescul $>$ Lád köve, Scarisoara $>$ Szekeres t., Toroiaga $>$ Toronyága, Vrf. Gogosia > Gögös h., Capu Mundului > Mondó feje stb. (Mikesy G. 2019).

A történelmi Magyarország felszabdalása után az utódállamok a magyar földrajzi nevek eltörlésében is az asszimilálásra törekvés eszközét látták. Kárpátalján 1946-ban következett be a nyelvi adaptáción lényegesen túlmutató ukránosítás: Komlós korábbi ruszin Комлушъ Komlus változatából fordítással keletkezett a hivatalos ukrán Хмільник Hmilnyik, hasonlóképpen (Bereg)kövesd esetében Кивяшдь Kivjásd helyett Камянське Kamjanszke lett, (Bereg)fogaras nevére pedig durva félreetimologizálással alkották а Зубівка Zubivka alakot, ugyanis az ukrán zub jelentése fog (SEbestyén Zs. 2010). A Felvidéken ugyancsak hosszú évtizedekig kikerültek a használatból a magyar helységnevek, és helyettük egyrészt lefordított, pl. Nagyudvarnok > Velké Dvorníky, Csallóköznádasd > Trstená na Ostrove, másrészt részben fordított, pl. Dióspatony > Orechová Potôň, Hidaskürt > Mostová, vagy éppenséggel minden történelmi elözmény nélküli neveket, pl. Megyercs > Čalovec, Peszektergenye > Sikenica erőltetett az utódállam.

Erdélyben nemcsak minden magyar településnek adtak román nevet 1918 után, hanem sok esetben (jellemzően az 1950-es és 1960-as években) erősen román többségü vidékeken is megváltoztattak hagyományos, a románban jól meghonosodott elnevezéseket is, ha azok a magyar nyelvű alakra emlékeztettek, például (Maros)kövesd Cuieşd > Pietriş és Hosszúaszó Hususău > Valea Lungă esetében (Murádin L. 2003, BartosEleKes Zs. 2013).

A térképekről lekerültek magyar mikrotoponimák is. Például a tisztán magyar Ipolyszalka csehszlovák kori kataszteri térképén (ill. még ma is) a következő - minden bizonnyal a magyar kataszteri térképi adatok fordításával előállt - nevek jelentek meg: Gödör alja > Podjamou, Hegyköz > Medzivršie, Belsö-Félhold > Vnúterný značený hon, Pokolfa > Pavúčistrom stb. (TöRöK T. 2011).

A nyelvi alapú beavatkozáson túl ideológiai célzattal is megváltoztatták helyek nevét. Ez leggyakrabban a közterületneveken mutatkozott meg - erre itt nem is térek ki -, de 
nem maradhattak ki a folyamatból a helységnevek és (ritkább estekben) más névtípusok sem. A Pest megyei Zsidó nevét 1943-ban antiszemitizmusra visszavezethető okokból változtatták Vácegressé. Az újabb rezsimet az 1950-es években az egyházellenesség és a feudális hagyományok eltörlésének szándéka motiválta, így lett Püspökszenterzsébetből Erzsébet, Koháryszentlőrincből Nyárlőrinc, Nemespátróból Pátró stb. A szovjetek felé tett gesztusként értékelhető Leninváros és Sztálinváros, majd e nevek megváltozása Tiszaújvárossá és Dunaújvárossá ugyancsak ideológiai fordulatot jelentett. Az ideológiai beavatkozás megjelent a mikrotoponímiában is. Az egykor tisztán német Tolna megyei község, Mözs külterületének birtokrendezésekor, 1936-ban az új dülők Horthy-dülö, Ferenc József-dülö, Szent István-dülő, Ezeréves-dülő neveket kaptak, melyeket természetesen azonnal lecseréltek a szocialista kormányzat idején (Mıkesy G. 2013).

\section{A FÖLDRAJZI NEVEK MINT A KULTURÁLIS ÖRÖKSÉG RÉSZE}

Minden földrajzi névnek, névadási hagyománynak megvan a maga kultúrtörténete, lényegében ilyenekről szóltak az előző fejtegetések is. Felismerve, hogy a világ kulturális örökségének a földrajzi nevekben megőrzött részeit számos veszély fenyegeti egyrészt a tájra és a társadalomra ható gyors ütemü gazdasági változások, másrészt az államok eltérő gyakorlata miatt, az ENSZ földrajzi nevekkel foglalkozó intézményei (elsősorban az említett ENSZ Földrajzinév-szakértői Csoport [UNGEGN]) ajánlások sorával hívta fel a figyelmet az utóbbi évtizedekben a földrajzi nevek olyan gondos kezelésére, hogy az támasza lehessen az egyetemes és a helyi kulturális örökségek megőrzésének, és az identitás biztosításánakaz egyes országokban, kimondva például, hogy

- bizonyos, az identitás és a folytonosság érzetét keltő toponimák használatát számos veszély fenyegeti (UNCSGN Resol. IX/4);

- nemzeti szinten intézkedéseket kell hozni annak biztosítására, hogy a még összegyűjtendő neveket a terepmunkák során a helyi szokásoknak megfelelően rögzítsék a névformák helyi használata szerint (UNCSGN Resol. VIII/9);

- a földrajzi nevek elismerése és védelme érdekében tekintetbe kell venni olyan kritériumokat, mint a név kora (első feljegyzésének ideje), az a képessége, hogy megtestesít kulturális, földrajzi, történelmi, társadalmi stb. valóságot, és lényeges összetevője a helyi, regionális vagy nemzeti identitásnak (UNCSGN Resol. X/3).

A hangsúly tehát a névkincs összegyüjtésén és a helyi alakok minden külső szempont nélküli tiszteletben tartásán van.

Magyar vonatkozásban, túl a nyelvi és történelmi vonatkozásokon, még két nagyobb fogalmi csoportot feltétlenül ki szeretnék emelni, a személyneveket és a foglalkozásokat. Helységnév őrzi a korai politikai és birtokosi elit tagjainak nevét: Fajsz, Taksony, 
Tas(s), Gyula, Szabolcs, Üllö, Solt, Tétény, Aba, Bács, Bars, Csanád, Hont, Poson(y) stb. Ezek jelentős része - hosszú évszázadok után - újra részei lettek adható keresztneveink körének, és legtöbbször abban a formában, ahogy azokat a helynevek megörizték. Van ellenpélda is: a Vazul név felújítása korábban történt, mint hogy a tudomány megteremtette volna a kapcsolatot a történelmi adat és a Veszprém megyei Vászoly település között.

A ma emberének idegenül hat, hogy személynevet tételezzen fel olyan motiválatlan hangsorok mögött, mint Baté, Gagy, Gencs, Gyán, Gyö, Ibrány, Iklad, Pentele, Szakmár, Szomód, Szöny, Tápé, Tokod, Tököl, Tömörd, Valk, Zsidány, Zsurk, vagy éppenséggel a hangsor mai közszói jelentése miatt furcsák, mint pl. Alap, Bugyi, Buják, Füle, noha a források meglehetős pontossággal igazolják ezt. Vannak személynevek, melyek viszont kizárólag helynevekben maradtak fent, pl. a Gencs és a Tard képzésmódja világos, éppen csak ilyen nevü személyre nincs adat.

A településrendszer középkori kialakulásának idején még csak egy neve volt az embereknek (a családnév később alakult ki), ezért szükség volt arra, hogy sok egyedi azonosítást biztosító személynév legyen. Ennek eszköze volt tucatnyi olyan névképző, amelyekkel ma már nem alkotunk neveket, de a középkorban virultak, és helyneveinkben megőrződtek. A -cs képzővel alakultak például az Adács, Bikács, Dancs, Dencs, Kércs, Megyercs, Pércs, Pócs; -d-vel az Álmosd, Ádánd, Atád, Báránd, Endréd, Fejérd, Istvánd, Jánd, Királd, Kölked, Lábod, Legénd, Peterd; -k-val a Bánk, Benk, Györk, Ispánk, Jánk; a -csa/-cse képzővel a Fejércse, Gecse, Kölcse, Tarcsa stb. nevek. További tucatnyi képző különíthető még el. A névképzők segítségével valóságos névbokrok születhettek, így például a Bene, Becske, Bedö, Bék, Beke, Benk falunevek mind a Benedek, a Páld, Pályi, Pall, Pócs, Póka, Pósa pedig a Pál személynévre nyúlnak vissza.

A magyar nyelvű bibliafordítások (a reformáció korától) a személynévhasználatban is új időket hoztak, amennyiben nem vagy nem feltétlenül a magyarban hagyományosan kialakult névalakokat tették nyelvi norma részévé. A helynevek tanúsága szerint a Saul névnek ugyanúgy alakult a korai magyar alakja, mint a Paulé (> Pál), azaz Sál lett az elsődleges alak (vö. Hegyhátsál, Salföld < Sálfölde, Sálfalva, Szamossályi stb.), a Mózes korábban használt Mojs, Mojse alakját őrzi Majs, (Kiskun)majsa, Majosháza, a Noét Nova és Novaj, Ábrahámot (Nyír- és Bükk)ábrány. Keresztelő Szent Jánosnak és több rokonnevü szentnek a kultusza igencsak korai nálunk, viszont a helynevekben az Iván alak többszöröse a Jánosnak (Bakonyszentiván, Cserhátszentiván, Sajkásszentiván, ill. Iván, Ivánc, Iváncsa stb.) A szent evangélisták nevére pedig lényegesen gyakoribb volt a Mátyus és Luka (vö. Mátyus, Mátyusföld, Mátyusvágása, ill. Lukafalva, Magyarlukafa, Lukailencfalva stb.), mint a Máté és Lukács. A középkori műveltséghez szolgálnak jó adalékot és a szentkultusztól független, világi névdivat mintáját mutatják a középkorban népszerű Trója-regényből és a Roland-énekből ismert személynevekkel alakult 
települések. Míg a magaskultúrában a személynevek megtartották idegenszerủ alakjukat, a településnevek másképp fejlödtek: Hektor $>$ Iktár, Akhilleus + falva $>$ Ehellösfalva $>$ Helesfa; Priamos > Perjámos, Trisztán > Terestyén (KÁlmán B. 1973, Kiss L. 1988).

Egyes személyek vagy a faluközösség fö tevékenységére utaló szavak többféle motiváció alapján válhattak helynévvé, egyrészt a falu kötelessége lehetett birtokosát (kegyurát, a kincstárat, egy monostort, egy várat stb.) valamilyen terménnyel vagy szolgáltatással kielégíteni, másrészt lehetett egy falu a mindenkori beszállító javadalma, továbbá a ritka tevékenységek személynévvé is válhattak, s látszólag foglalkozásra utaló helynevek tulajdonképpen a személynévi eredetű nevek állományát szaporítják. Mai nyelvérzékünk szerint is terjedelmes csoportról van szó, igen számos Halász Halászi, Kovácsi, Lovász Lovászi, Méhész, Molnári, Őr, Szakácsi, Tárnok, Udvarnok, Vadász, Vámos féle helynevünk van (Gyöngyöshalász, Pusztakovácsi, Hosszúlovász, Zalatárnok stb.). Nincs már meg a nyelvünkben az Esztergár, Fegyvernek, Hodász féle településnevek közszói elözménye, mégis felfedezzük bennük az esztergálásra, a fegyverek kezelésére, a hódvadászatra való utalást. A Fedémes Födémes nevek a kaptárokra, azaz méhészkedésre utalnak, ahogy a Mizdók is, Nagymizdó nevét először Noghmezadou formában jegyezték fel, azaz a község mézzel adózott. Hidvégardó, Beregardó, Feketeardó neveink második tagja az erdoóvó kifejezésből ered (1353: Erdeuouou). A Beregdaróc, Fülpösdaróc, Királydaróc, Tibolddaróc, Várdaróc stb. második tagja az elejtett vadak durva feldolgozását végzőkre (nyúzás, szaruanyagok, csontok kifőzése stb.) utal. Hőgyészeink névadói viszont a legfinomabb prémeket szállították, ugyanis a középkori hölgy szavunk a hermelint jelentette (KIss L. 1999). A vegyes hangrendű szláv tesár, azaz ács, gerendakészítő' szó korai kölcsönzéséből eredtek, így hangrendi kiegyenlítődéssel fejlődtek tovább a Teszér és Taszár nevek (pl. Ácsteszér, Pápateszér, Taszár, Barstaszár). A Csitárok és mély hangrendü párjai, a Csatárok pajzskészítő mesterekről (štitár) kapták a nevüket. A mečiár, azaz kardkovács szóból csak a magas hangrendü változat vált településnévvé, a Győr megyei Mecsér. Kutyák nevelésével foglalkoztak a Peszér nevü falukban (szláv pes 'kutya').

\section{A KÖZIGAZGATÁS NÉVIGÉNYE}

A társadalmi fejlődés egy magasabb szintjén - mint civilizációs érdek -, megjelenik az az igény, hogy néhány földrajzinév-típus esetében az egyedi azonosítás (tehát hogy az adott csoportban minden helynek egy neve legyen, és minden névalakhoz egy hely tartozzék) egész országra kiterjedően, szabályozottan, hivatalosan megállapított névalakokkal történjék. Az élet különböző színterein szükség van rögzített írásbeli formákra, például olyan állami tevékenységekben, mint az anyakönyvezés rendszere, a lakcímés ingatlan-nyilvántartás, az országos statisztika, a nagy közszolgáltatások (közösségi 
közlekedés, posta, egészségügy stb.) szervezése, de hosszan folytathatnánk a sort a tudományok, az oktatási anyagok és a sajtó világával. Elsősorban a helységek és a közterületek nevének vonatkozásában (egy helységen belül) van rendszerkényszer, de több más névtípusban is vannak ágazati, helyi követelmények.

Magyarországon a 19. században még több tucat helység viselte az Újfalu, Keresztúr, Keszi, Megyer, Szentmárton, Szentandrás stb. neveket. Az előtaggal való megkülönböztetés rendszere (pl. Nagydobsza, Kisdobsza) spontán alakult ki, majd az előző századfordulón felálló Országos Községi Törzskönyvbizottság is a leggyakrabban ezt a módszert alkalmazta úgy, hogy a megyék, közeli városok nevét is felhasználta. Így, hivatalos névadással alakultak ki a helységneveinkre oly jellemző névbokrok: Drávaszerdahely, Dunaszerdahely, Kaposszerdahely, Magyarszerdahely, Muraszerdahely, Nyitraszerdahely, Tótszerdahely, illetve Zalaegerszeg, Zalahaláp, Zalaistvánd, Zalakaros, Zalakoppány, Zalalövö, Zalamindszent, Zalaszentiván, Zalaszentlörinc, Zalatárnok, Zalaudvarnok stb. A közhiedelemmel ellentétben az egyszerü alakok nem valami lustaság vagy hiba miatt vannak még meg az élő helyi névhasználatban, hanem mert azok az eredeti formák. Másféle egyedítés is volt, pl. a két Lökösházából az egyiknek el kellett hagynia a -háza utótagot. A történelmi Magyarország területén több ezer község nevét hivatalos úton állapítottak meg (Mezö A. 1982, 1999). Helységek közigazgatási összevonása áll számos furcsán hosszú név mögött: Bernece + Baráti > Bernecebaráti, Csokva + Omány $>$ Csokvaomány, Mosonszentjános + Pusztasomorja > Jánossomorja, Hagyáros + Börönd > Hagyárosbörönd, Nyírbakta + Lórántháza > Baktalórántháza stb.

\section{EXONIMÁK}

Exonimákon egy nyelv azon földrajzi neveit értjük, amelyek kívül találhatók azon a helyen, ahol a nyelvet széles körben beszélik. Így tehát exonima a magyarban a Bécs, Párizs, Peking, Varsó, de nem az Beregszász, Csíkszereda, Fülek, Szabadka a határok ellenére sem (Bartos-Elekes Zs. 2002). Az exonimákat tekintve meglehetösen különböző kiadványokkal találkozunk. Sok térképen csak a hivatalos nyelven tüntetik fel a neveket, máshol a célközönség nyelvén vannak a nevek a lehetséges mértékig. Az utóbbi szempont csábító lehetőséget kíván a patrióta attitüd kimutatására, például történelmi névanyag felelevenítésére modern tematikában (és sajnos sosem volt nevek bevezetésére is). Az előbbi tekintetében igen vékony és a szubjektív megítélésektől erősen függő az a vonal, hogy mely neveket tarthatunk az élő, és melyeket a történelmi névréteg részének. Az exonimák alakulását és vitalitását a hely aktuális jelentősége határozza meg (régebben a közvetlen kapcsolatok, újabban a turizmus, sajtóhírek, és leginkább az, hogy a tananyagoknak része-e). Pl. a dalmáciai városok esetében - úgy tünik - eldőlt, hogy a tömeges turizmus következményeként az 
Opatija, Dubrovnik, Split stb. felülírták a magyarban hagyományosan használt, az olaszból eredő Abbázia, Raguza, Spalato stb. alakokat (BöLCSKeI A. et al. 2018). A Habsburg időkben néhány külföldi város magyaros alakja helyett a német változat honosodott meg, így például a Lemberg, Olmütz, Königgrätz alakok dominánsabbnak bizonyultak mind a régi (valószínűleg csak szórványosan elterjedt) magyar Ilyvó, Alamóc, Királynégréce, mind a helyi Lviv Lwow, Olomouc, Hradec Králové alakokkal szemben. Itt tehát két, történetileg jól elkülöníthető exonimaréteget látunk. A lengyelországi Boroszló (Wrocław, Breslau) ismerete szinte a szemünk előtt tűnt el (a mi nagy- és dédszüleink világában még elsődleges formának számított), a Dancka (Gdańsk, Danzig) pedig még egy generációval korábban.

Mint minden földrajzi név esetében, az exonimahasználatnak is hiteles forrásokra kell támaszkodniuk. Újabban számos olyan névalak kapott nagy nyilvánosságot, melyeket célzatosan és tudálékosan alkottak, és kevésbé sikeres etimologizáláson vagy a történeti források rugalmas kezelésén alapulnak. A Google Maps-en például (magyar oldalakról indulva) a dél-morvaországi Břeclavot Leventevár, Moldova fővárosát Kisjenö, a csángók Bákótól délre fekvő központját Ónfalva néven tüntetik fel. Terjedőben van Szucsáva (Suceava) helyett a Szücsvár használata. Ezekben közös, hogy a magyar névalak használata semelyik korból nem mutatható ki. A csángók például - a korábbi források szerint is - magyar beszédben is csak az Onyest alakot használták, Ónfalvát nem.

Összegzésként röviden talán annyit lehet mondani, hogy a földrajzi nevek egy nép múltjába, szokásaiba, nyelvének rejtelmeibe, kisebb régiók, falvak belső világába nyithatnak kaput, mérhetetlenül gazdag forrást biztosítva azoknak, akik be akarnak lépni rajta. Számos megközelítési mód lehetséges, amelyekből csak néhányat tudtam ebben a terjedelemben megidézni, de ezeket törekedtem különböző területekről összeválogatni.

\section{IRODALOM}

Bartos-Elekes Zsombor (2002): Helységnevek a romániai köztudatban. - Geodézia és Kartográfia 55. 4. pp. 19-24.

Bartos-Elekes Zsombor (2013): Nyelvhasználat a térképeken (Erdély, 19. és 20. század). - Kolozsvári Egyetemi Kiadó, Kolozsvár. 210 p.

Bényei Ágnes (2012): Helynévképzés a magyarban. - Debreceni Egyetemi Kiadó, Debrecen. 134 p.

Bölcskei Andrea - Farkas Tamás - Slíz Mariann (szerk.) (2017): Magyar és nemzetközi névtani terminológia. Hungarian and International Onomastic Terminology. - Magyar Nyelvtudományi Társaság - International Council of Onomastic Sciences, Uppsala-Budapest. 240 p. https://doi. $\operatorname{org} / 10.26546 / 5061110$

Bölcskei Andrea - Gercsák Gábor - Mikesy Gábor (2018): Hol van Abbázia? Egy kérdőíves felmérés tanulságai. - Névtani Értesítő 40. pp. 103-117. https://doi.org/10.29178/NevtErt.2018.6 
FÁbián PÁl - Földi ERvin - HőNyi Ede (1998): A földrajzi nevek helyesírása. - Akadémiai Kiadó, Budapest. 132 p.

GyÖRFFY GYÖRGY (1963-1998): Az Árpád-kori Magyarország történeti földrajza I-IV. - Akadémiai Kiadó, Budapest. 908 p.

HajDÚ MiháLy (2003): Általános és magyar névtan. - Osiris Kiadó, Budapest. 955 p.

J. Soltész Katalin (1979): A tulajdonnév funkciója és jelentése. - Akadémiai Kiadó, Budapest, 208 p.

KÁLMÁn BÉLA (1973): A nevek világa. - Tankönyvkiadó, Budapest. 260 p.

KÁzmér Miklós (1970): A »falu« a magyar helynevekben. XIII-XIX. század. - Akadémiai Kiadó, Budapest. $316 \mathrm{p}$.

KIss Lajos (1988): Földrajzi nevek etimológiai szótára I-II. - Akadémiai Kiadó, Budapest. 822 + 824 p.

Kiss Lajos (1992): Cuius regio, eius nomen? - Magyar Tudomány 99. 2. pp. 129-135.

Kiss Lajos (1999): Történeti vizsgálatok a földrajzi nevek körében. - Pázmány Péter Katolikus Egyetem, Piliscsaba. 356 p.

LANSTYÁk IstváN (2017): Nyelvi ideológiák (általános tudnivalók és fogalomtár). - http://web.unideb. hu/ tkis/li_nyelvideologiai_fogalomtar2.pdf [2021. október 13.]

Mező András (1982): A magyar hivatalos helységnévadás. - Akadémiai Kiadó, Budapest. 408 p.

Mező AndRÁs (1999): Adatok a magyar hivatalos helységnévadáshoz. - Nyíregyháza. 576 p.

Mikesy GÁвоR (2008): 20. századi társadalmi változások hatásai a helynevekre. - In: Hoffmann István - Tóth Valéria (szerk.): Helynévtörténeti tanulmányok 4. Debreceni Egyetemi Kiadó. Debrecen. pp. 143-148.

Miкesy Gábor (2013): Érdekes helynevek - helynévi érdekességek. - In: Balázs Géza - Grétsy László: Helyneveink érdekességei, tanulságai, népi magyarázatai. Anyanyelvápolók Szövetsége. Tinta Kiadó. Budapest. pp. 203-215.

Mikesy Gábor (2019): Tömeges helynév-magyarosítás a térképeken (1894-1944). - In: Vörös Ferenc: A nyelvföldrajztól a névföldrajzig X. Nevek a nyelvpolitikai küzdőtérben. Savaria University Press, Szombathely. pp. 173-190.

Murádin LÁszló (2003): Utak és nevek. Településnevek erdélyi utakon. - A Magyar Nyelv és Kultúra Nemzetközi Társasága, Budapest. 218 p.

Nicolaisen, Wilhelm F. H. (1986): The structure and function of names in English literature. - Studia Anglica Posnaniensia 18. pp. 139-152.

RÁCZ Anita (2016): Etnonimák a régi magyar településnevekben. - Debreceni Egyetemi Kiadó, Debrecen. $196 \mathrm{p}$.

Sebestyén Zsolt (2010): Bereg megye helységeinek etimológiai szótára. - Bessenyei Könyvkiadó, Nyíregyháza. 168 p.

TöRÖK TАмÁs (2011): Ipoly mente helynevei. - Fórum Kisebbségkutató Intézet, Somorja. 144 p.

ÁTI Pilis hegység 1:50000 (é. n.). Kirándulók térképe 2. szám. - Magyar Királyi Állami Térképészet.

UNCSGN Resol. (é. n.): Resolutions adopted at the eleven United Nations conferences on the standardization of geographical names. Prepared for the United Nations by Natural Resources Canada. pp. i-xiii + 131. https://unstats.un.org/unsd/ungegn/documents/RES_UN_E_updated_1-11_CONF.pdf 